\title{
LITERATURE OF PROTEST: JACK LONDON'S THE IRON HEEL, A SATIRICAL PERSPECTIVE
}

\author{
Saeed Yazdani ${ }^{1}$, Mohammadreza Shahbazi ${ }^{2}$ \\ ${ }^{1}$ Department of English Literature, Bushehr Branch, Islamic Azad University, Bushehr, Iran \\ Saya134074@yahoo.com \\ 2 Department of Dramatic Literature, Bushehr Branch, Islamic Azad University, Bushehr, Iran \\ mrsh3072@yahoo.com
}

\begin{abstract}
Although literature of protest does not directly lead to social change, it can permanently change society during an awakening, a period of cultural revitalization that occurs during times of social stress and confusion. Because there have been so few awakenings, literature of protest has little effect on moving people in a certain direction. Though many protests have failed, many have also prevailed and led to great social change, Jack London's utopian satire, The Iron Heel, mainly intended to manifest London's contemporary Oligarchy, has been one of such works.
\end{abstract}

This article sheds light upon such a literature that has led to these changes through satirical comments made by the American novelist, Jack London, in his utopian satire, the Iron Heel.

Keywords: Protest, Satire, Oligarchy, Social Change

\section{INTRODUCTION}

Literature of protest and satire in particular, has been an important media through which the plight of mankind in the world has been voiced. Richard Wright once said "All literature is protest. You can't name a single literary work that isn't protest." His statement is correct. Most of the authors disguise their frustrations and problems of their time into their books. Although many people may not realize it, sometimes there is a deeper meaning behind the story.

Literature of protest is a type of protest that finds itself in the work of novels and other types of written work. To be considered protest literature, a work does not have to actually change a problem, but to provide society with reasons why something is a problem and perhaps give possible solutions. It is believed that all works of art offer a point of view; these works can still be considered protest literature. It is what people do after reading and seeing these works of art that bring about social change. Many of these writers who display their protests through their works seem to be tireless crusader for social justice and righteousness; they are considered as protagonists who stand for the intellectual enlightenment of their contemporary people. They are a group of zealous missionaries whose mission is social reform. Their criticisms are destructive, if it be destructive to break the chains which have held society in mental servitude. Some of these writers intend to liberate their age from mental sloth, social apathy, superficial sentimentalism, collective selfishness and the cruelties imposed on them by the masters. The literature of protest has been in connection with numerous and sundryanti-imperialism, pacifism, racial equality, sexual liberation, gay and lesbian rights, organized labor, environmentalism, and so. Behind these various movements a generalized critique of Western society and 
politics emerged, feeding and shaping the culture of protest and informing a distinctive style of expression that was shared by generations of writers, artists, and activists who defined themselves in opposition to the status quo.

With the emergence of satire as a means of expression, in the literature of protest, the targets of attack likewise came into focus, albeit in very generic terms such as, Consumer capitalism, alienation, objectification, subjugation, oppression and totalitarianism; the establishment transformed into a nightmarish vision of the West due to the experience of fascism, the holocaust, the Second World War, and its aftermath. Several international avant-garde movements influenced both this generalized critique and its characteristic style of expression in powerful ways. Thus here a definition of satire is essential in bringing about the basic elements of protest.

In my opinion, literature of protest must not necessarily bring about social change. One protests when one disagrees with something or someone. Literature of protest is a type of protest that finds itself in the work of novels and other types of written work. To be considered a protest literature, a book does not have to actually change a problem, but to provide society with reasons why something is a problem and perhaps give possible solutions. It is believed that all works of art offer a point of view; these works can still be considered protest literature. It is what people do after reading and seeing these works of art that bring about social change. Many of the writers who display their protests in their works seem to be tireless crusader for social justice and righteousness; they are considered as protagonists who stand for the intellectual enlightenment of their contemporary people. They form a group of zealous missionaries whose mission is social reform. Their criticisms are destructive, if it be destructive to break the chains which have held society in mental servitude. Some of these writers intend to liberate their age from mental sloth, social apathy, superficial sentimentalism, collective selfishness and the cruelties imposed on them by the masters.

\section{SATIRE AS A MEANS OF PROTEST}

Literature of protest and satire in particular, has been an important media through which the plight of humankind in the world has been voiced. The critical movements in literary studies including new historicism and cultural materialism have transformed the ways in which we read early modern texts. But while critics have focused superbly on genres such as epic, pastoral and love poetry, satire has somehow faded into the background. Readers of satire have remained perforce heavily reliant on formalist and New Critical studies. In line with my approach towards literature of protest throughout the book, it will be worth attending to contemporary perceptions of satire, the functions it has served within its culture, and the conventional stances and strategies adopted by satirists.

Satire always flourishes in a society which seems to have been civilized, a society where artificial life rendered necessary by city existence has driven men, emotionally and morally, to be cut off from elemental conditions and primitive impulses. This kind of protest in the form of satire seems to be a marked feature of the 20th century literature. Satire is concerned with acts of revelation rather than strategies of fabrication, and with attacks on agreed sins rather than particular sinners. Consequently, even what might initially appear libelous and scurrilous, and what might seem merely gratuitous descriptions of sinfulness, are supposedly underpinned by the most soundly orthodox of moral principles. Satire has become, in many respects, pervasive, an attitude or an inflection as a literary genre. Satirists aim to speak the truth, using their powers of forensic inquiry to expose vice, and their conventions of outspokenness and didacticism to heal with lashing.

That story of civil disobedience, meeting civil manners, is not a bad way to sum up a sometimes subtle division in American literature. On the one hand, there is art. On the other hand, there is art with a direct purpose, i.e., literature meant to spur action; to convey anger and shock; or to prompt empathy, based on a discontent with the status quo. That is, protest literature. The origin of satire lies in a state of mind which is aggressive and critical. The satirist tends to expose human absurdity, inefficiency and wretchedness of the victim. The difference between satire and other literary forms is that satire requires a special attitude to human experience. In satire there is an element of criticism which is based on the experiences undergone by the satirist. Satire might occur episodically in a novel, though the whole work might not be satirical in its tone. Satire must essentially keep two visions always parallel, the actual and the ideal. The actual is usually corrupt, but at every point its corruption suggests the ideal, man and his institutions as they should be. Thus every condemnation of man and society by the writers can suggest what can be done to remedy the situation. (Pollard 1970)

An important kind of satire is political satire; it generally contains elements of aggressive attack. The first important condition necessary for the satirist to write an important and effective political satire is a degree of free speech either by the satirist or the personae; the satirist should not have the slightest fear of being 
persecuted by the establishment or by the object of attack. The second condition is the general readiness and the interest of the educated class to take part in political affairs. There must be a general discontent with the state of affairs. The satirist looks forward to a positive response from the readers.

The third condition is that the satirist must have great confidence that his insights in to the affairs will have positive influence on the society, i.e. he must believe that he can reform his or her contemporary society. The satirist must also have wide experience of political change and engage himself in the troubles of the world, expecting his readers to do the same.

The main objective of satire is the amendment of vices by correction. Indeed, there are five essential attributes of satire: a) Literary form of expression, b) Disgust and indignation at the ugly, the foolish and the wicked, c) Humor, d) A sincere desire to correct or reform, e) Some exaggeration of reality.

A good satirist is a critic whose aim is to reform or correct human or social weaknesses, vices or follies. He might use different devices for this purpose which are going to be further elaborated in the following chapters. Satire is the moral indignation of the satirist at human wickedness, vice or folly which distinguishes him from a true humorist who is always gentle and sympathetic in his laughter. A humorist laughs with others, while a satirist laughs at others. A satirist is often bitter, critical and sharp.

For effective satire, the satirist uses such tones as ridicule, wit, irony, sarcasm, cynicism, and exaggeration, the sardonic and invective, and even obscenity. All these tones are meant to hurt. Ridicule makes the subject look like a fool. Sarcasm is ungenerous; the reader must know the true state of the things in order to understand sarcasm. Pessimistic and disillusioned cynical laughter is contemptuous. A sardonic is another pessimist; he is on the verge of unbearable anger and hatred; he laughs to control his anger - which leads to an important satiric tone, namely, invective which is somehow found in the works of the pioneers of the literature of protest. The satirist also uses several reductive methods. He reduces men to equality and humbles the mighty; the removal of rank and status makes people equal. He might even reduce man to the condition of an animal - by using animal analogies and images. In this way the satirist tends to deflate false heroes who claim respect which is not due to them. A satirist who uses invective attacks his targets directly, and may use abusive language. Invective can lead to vulgarity. It "requires elegance of form to set off grossness of content, and learned allusiveness to set off open insult" (Hodgart 130).In narrative form, it allows a double flow of meaning. A satirist might also act as the mouthpiece of people's indignation. His target of attack may be the system or individuals. He or she may create fantasies and insert in them powerful images of the real world and its leaders; he uses imaginary visions and denounces tyranny and stupidity of the tyrants directly.

Another basic device used by satirists is unmasking; this is another form of the reduction technique. It degrades its objects through parody and travesty. A satirist usually "puts on a mask for the purpose of unmasking others. He strips off his victims' symbols of rank and their clothes to reveal the corrupt nakedness beneath." A satirist refuses to allow the victim to remain with any person of his own, or with any secret. He sees "the skull beneath the skin, the hideous and shameful disease beneath the smooth envelop of skin" (Hodgart I28). The satirist displays the noblemen and the wealthy as: "Charlatans selling their political quack-medicines, next in a ludicrous and farcical procession, and finally their leaders make speeches which travesty the policies of their party. The satirical technique is the simple and effective one of naïve self-revelation: the characters cannot help exposing their true intentions, and passing judgment on themselves" (56).

The satirist might go below to the realm of the automatic. The object of satire usually is a rational man who is able to realize the nature of his wrong acts. The object is neither a madman nor an ignorant person. Satire presents human life in terms of largely unrelieved bondage; this form is set in madhouses, prisons of endless pains, and places of executions; it considers death as the only means of relief and escape from the sufferings, for the tortured hero.

The necessity for reform in the 20th century society, be it the United States or other places in the world, urged such writers like Jack London to voice their concerns over the social problems through literary protest; this protest rather than being in the form of direct attack and armed struggle against the dominant class, manifested itself in the form of a literary form, satire. Pointing to the close connection between satire and politics, in his treatise Satire, Hodgart says:

Both are necessary, since all social and legal systems are in need of continuous reform, and politics is the only means of achieving reform; while only satire can release powerful enough acids to break down the attitudes of mind which hinder reform. Most of the great satirists have in fact been deeply interested in politics, and most have been against the established government of their countries. (33) 
Traditionally, the elements of attack and humor are associated with the term "satire". Satire tends to expose the things as they are. It portrays the difference between things as they ought to be and as they are. It deflates its objects. It can be considered as a kind of protest. Satire demands a high degree of involvement with the painful problems of the world.

According to Simpson, in On the Discourse about Satire (2003), satire clearly has "an aggressive function"; it singles out an object of attack. Satire also has a social function. Simpson believes:

Satire functions as a higher-order discourse, in the Foucaultian sense; higher than what systemic-functional and other linguists classify as genre or register, and certainly higher than what literary-critics traditionally mean by the term "genre of literature". Satire requires a genus, which is a derivation in a particular culture, in a system of institutions and in the frameworks of belief and knowledge which envelop and embrace these institutions. It also requires an impetus, which emanates from a perceived disapprobation, by the satirist, of some aspect of a potential satirical target. (Simpson, 23)

The satirist may act as dramatist, a novelist, a performer, a spectator, an assailant or victim of violence, and a jurist or criminal. Satirists, then, do not just describe, distort, and criticize social life. They claim to intervene in it as well—at least in an indirect manner through their texts. Besides parading and exposing vice, satirists may strike back at it metaphorically. The satiric process is often likened to physical aggression. Satirists attack, bite and lash; their work is scathing, cutting, and piercing. Physical violence is just under the surface in literary satire, but the exact relationship between the two practices requires some untangling to be understood.

\section{JACK LONDON'S THE IRON HEEL}

\subsection{The Iron Heel: A Utopian Satire}

As years passed by, Jack London's faith in the possibility of gaining a socialist utopia through the ballot box reduced. He saw it as his duty to carry the flag of revolution, to beat down the powerful strength of ever-growing capitalism in the United States. He warned his comrades not to underestimate the destructive power of capitalists who controlled the establishment and such institutions as the police, the courts, the press, etc. In his proletarian novel The Iron Heel (1907), London intended to warn his comrades in the Socialist Party of the destructive power the capitalists could display. The pessimistic theme of the novel is the rise of Oligarchy. He satirizes both his prevailing contemporary ruling class, and his pacifist comrades in the Socialist Party.

The novel has an elaborate framework. It is in the form of a manuscript written by Avis Everhard between 1912 and 1932; seven centuries later, it is found by a historian, Anthony Meredith, who undertakes to publish it. As editor, Meredith makes comments in footnotes for the benefit of 27 th century readers. He views the events of the early 20th century, 1912-1932, in the 27th century, the time the manuscript is found. Avis Everhard, a member of the Oligarchy herself, narrates the events in first person; being a character in the novel she also makes observations on the events. Ernest Everhard, a fiery revolutionary, is the protagonist of the novel; it is his story that Avis narrates. There are thus three characters that Jack London uses for his own comments: Avis Everhard, Ernest Everhard and finally the fictional editor, Anthony Meredith. Each of these characters allows London to criticize attack and expose his contemporary society in a different way and from a different standpoint.

The Iron Heel is a political satire and an attempt by London to reform his own contemporary society. Avis and Ernest Everhard, and the fictional editor Meredith are three different personae or masks for Jack London.

The manuscript is about the disastrous First Revolt against the Oligarchy led by Ernest Everhard and his socialist comrades. Avis Everhard, Ernest's wife, narrates the story of Ernest's life and his execution at the hands of oligarchs in 1932. The narration ends somewhere during the last days of preparation for the Second Revolt. No record of the whereabouts of Avis Everhard, who has left the manuscript incomplete, is found by the fictional editor, Meredith. As a member of an oligarchic family, Avis Everhard has had opportunity to be educated at the university but she has only been reading books with no practical observation of the facts. When Ernest Everhard enters her life and acquaints her with the deceptive conventions of the Oligarchy, she decides to find out the truth for herself and investigate the validity of what Ernest Everhard exposes about her class.

As mentioned in the earlier chapter, unmasking is a device used for satiric reduction. The satirist may pretend to be a detective or a spy and take delight in discovering the secret lives of other people. In The Iron Heel, Avis Everhard serves as a spy, an investigator. The satiric exposure is woven into the action of the novel. She is set to uncover the hidden reality of Jackson's accident which has led to the loss of the latter's arm; in the process, she finds out various things about lawyers, judges, labor leaders, the press and rich ladies of her own 
class. It is through these insights that Avis gains the proper enlightenment and is converted from a member of an oligarchic family to a revolutionary.

Ernest Everhard is in the present time of the novel; his presence enables London to attack his own contemporaries directly. The novels begins with the party held at the house of Prof. Cunningham and first group of people who are attacked by Ernest are the learned and the clergy who have attended the party followed by the members of the Philomath Club, the middle class businessmen, the trusts, and the senators.

Meredith's comments appear in the form of footnotes that is a skillful device used by Jack London in his work. Meredith belongs to a period of seven centuries later; the only difference between him and London is that the former lives in the future and belongs to an ideal socialist utopia named Brotherhood of Man, which is supposed to have been achieved in the 27th century. The values and conventions in Meredith's time differ from those of London's times. The fictional editor comments on the struggle of Everhard and his contemporaries from a later, wiser and socialistically ideal stand point; he is not impressed by the happenings in the novel and can make dispassionate and objective comments on the events. Meredith is an outsider who is used by London to make jibes at everything. At the beginning of the novel, Meredith makes a comment, which serves as an introduction to the pessimistic tone of the novel:

Too late did the socialist movement of the early twentieth century divine the coming of the Oligarchy. Even as it was divined, the Oligarchy was there - a fact established in blood, a stupendous and awful reality. Nor even then ... was any permanence attributed to the Iron Heel. Its overthrow was a matter of a few short years, was the judgment of the revolutionists. It is true, they realized, that the First Revolt was premature; but they little realized that the Second Revolt was doomed to equal futility and more terrible punishment. (Novels and Social Writings 321)

Through Ernest Everhard, London makes critical and hostile comments on the political and social life in a society dominated by the Oligarchs. Everhard is depicted as even a stronger and bitterer foe of the capitalists than London. A member of the proletariat, Ernest Everhard, during his earlier years, had thought that all things up above him were "noble and gracious". He had met keen intellectuals and ministers of the Gospel who had been broken because of their critical approach to Christianity, and finally professors who have been "broken on the wheel of university subservience to the ruling class"; these and many others such observations have made him disappointed with the upper class. He had been taken aback by the selfishness and intellectual stupidity of the upper class people who "prattled sweet and dear moralities" but lived a "materialistic" life. These upper class men invoked the name of the "prince of peace" as if they were against war while ironically putting rifles in the hands of the mercenaries of the Oligarchy in order to kill strikers.

Ernest's first target of attack is the metaphysicians. Avis relates the first challenge that Ernest took up against the metaphysicians and idealist philosophers present at her father's dinner table. At this meeting, Ernest launches his attacks on the metaphysicians; he calls them "anarchists in the realm of thought" and "mad cosmos-makers" (327). His tone is ironical and mocking. He tells them that they "separate sincerity from truth". $\mathrm{He}$ is almost sneering when he tells them that they remind him of "the scholastics of the Middle Ages who gravely and learnedly debated the absorbing question of how many angels could dance on the point of a needle. Why, fifty dear sirs, you are as remote from the intellectual life of the twentieth century as an Indian medicine-man making incantation in the primeval forest ten thousand years ago" (328).

He asks the physicians if they have done anything about humankind, and tells them that they have done nothing but spin "airy fancies"; while the scientists were building roads and granaries, the metaphysicians have been busy building "gods in their own shapes", and considering famine as being a "scourge of God" instead of trying to fight against it. (330) He flays them with his facts: "each fact is a lash that stung and stung again." Obviously, Jack London enjoyed giving the metaphysicians the lashing through Ernest Everhard. In a tone of ironical pity, he continues: "But you are not to be blamed for this. You herd with the capitalist class... that pays you, that feeds you. And in return you preach to your employers, the brands of metaphysic that are acceptable because they do not menace the established order of society. (335)

One of the belittling devices used for satire is pointing out ugly physical features of the victims. This is what London does for belittling his victims. Everhard, tells the metaphysicians and the clergy to leave the working class alone, because they have nothing in common with the latter. He tells them: "Your stomachs are round with the plentitude of eating" (335). Later, he accuses the clergy of preaching to the sleek full-bellied recipients of dividends, paid out of the blood of the laborers. London uses the technique of reduction, devaluing and degrading his victims by pointing out to their faults and weakness through the unlearned Everhard. London reduces his victim by removing from him all the supports of rank and status, and shows to his reader that there is nothing underneath except an ordinary mortal. 
In his encounter with Bishop Morehouse, Everhard uses abusive language mingled with ridicule. He goes on fluently with remorseless logic and firm grasp of facts to explain that the average person is selfish; that each wants the best share of the things he can get. Bishop Morehouse lacks vigor in argument and talks idealistically. Everhard tells the Bishop: "You have gone up in the air and are arranging a division between the kind of men that ought to be but are not" (342). London uncovers the true faces of those who consider themselves responsible for bringing salvation amongst the masses. The church is an old subject of satire; it has supported political tyranny. Jack London treats the hypocrisy of the church with irony when he has Everhard tell Bishop Morehouse:

A century and a half ago, originated the modern proletariat. Moreover, the Church ignored it. While the capitalists made a slaughterhouse of the nation, the Church was dumb. It did not protest, as to-day it does not protest. As Austin Lewis says, speaking of that time, those to whom the confined, 'Feed my lambs' had been given, saw those lambs sold into slavery and worked to death without a protest. (344-345)

"The Church," he declares, "is not teaching Christ these days; it condones the frightful brutality and savagery with which the capitalist class treats the working class" (344). Exposing the clergy's utter separation from Christ, Ernest sneers, "yet the command to the Church was, "Feed My Lambs", When have you protested to your capitalistic congregations "at the working of children in the Southern cotton mills?" (345-346)

In the course of the discussion, the Bishop's words become weaker and weaker in their logic. He can only weakly protest: "it is wrong; it is so short-sighted on the part of the workingmen" (343). And finally, when confronted directly with the Church's failure to protest at the capitalists' treatment of the working- class, and thus having become an accomplice of the capitalists, he confesses: "I had not looked at it in that light. You must be wrong"(344). At the end of the discussion, Everhard offers to take the Bishop on a journey through hell, to see the things for him.

Together with the narrative runs the commentary of the fictional editor who explains things in simple terms for the benefit of the 27th century reader in the footnote. One of these terms explained is "Proletariat," which, he defines as a word "derived originally from the Latin 'proletarii', the name given in the census of Serving Tullius to those who were of value to the state only as the rearers of offspring (proles); in other words, they were of no importance either for wealth, or position, or exceptional ability" (344). This dispassionate, bland explanation given by Meredith on the capitalists enables London to make oblique comment on the structure of society created by the powerful Oligarchy. Meredith once again gives a clear picture of the treatment of labor by the Oligarchy: "There is no more horrible page in history than the treatment of the child and women slaves in the English factories in the latter half of the eighteenth century of the Christian Era. In the industrial hells, arose some of the proudest fortune of that day" (345). This biting comment made through Meredith, gives a true picture of the exploitation of the masses, in particular, helpless women and young children, by the Oligarchs. The discriminative social injustice inflicted upon the poor by the upper class is exposed through Meredith's note on thieving in London's contemporary times: "In those days thievery was incredibly prevalent. Everybody stole property from everybody else. The lords of society, stole legally or else legalized their stealing, while the poorer classes stole illegally" (350).

It is an oblique comment on the social injustice and double standards. The device of footnoting allows Jack London to pile up his satiric attacks on 20th century attitudes and conduct. In the style of a research scholar, Meredith "appends" several instances, culled from documents of the times, to demonstrate 20th century attitude to slavery. The footnote states:

In 1835 A. D., the General Assembly of the Presbyterian Church resolved that: 'slavery is recognized in both the Old and The New Testaments, and is not condemned by the authority of God. 'The Charleston Baptist Association issued the following, in an address, in 1835 A.D.l' The right of masters to dispose of the time of their slaves has been distinctly recognized by the Creator of all things, who is surely at liberty to vest the right of property over any object whomsoever He pleases. 'The Rev E. D. Simon, Doctor of Divinity and professor in the Randolph - Macon Methodist College of Virginia, wrote: 'Extracts from Holy Writ unequivocally assert the right of property in slaves, together with the usual incidents to that right. The right to buy and sell is clearly stated. Upon the whole, then, whether we consult the Jewish policy instituted by God Himself, or the uniform opinion and practice of humankind in all ages, or the injunctions of the New Testament and the moral law, we are brought to the conclusion that slavery is not immoral. Having established the point that the first African slaves were legally brought into bondage, the right to detain their children in bondage follows as an indispensable consequence. Thus we see that the slavery that exists in America was founded in right'. (434) 
As Everhard tells Avis and Bishop Morehouse about the hypocrisy of their class, the conversation turns to the loss of Jackson's arm in a factory accident. Ernest explains how the accident occurred.

Jackson had suffered unbearable fatigue, which led to slow movements, loss of resilience and snapping of muscles, all of which caused the accident. The Sierra Mills had a shrewd lawyer. Colonel Ingram, who won the damage suit brought up by poor Jackson and as in reward, Jackson was thrown out. He has been a victim of a conspiracy wrought by a corrupt capitalist system, which holds the judiciary in control.

Everhard, suggests to Avis that she should investigate Jackson's case. Both Bishop Morehouse and Avis have accepted Ernest Everhard's challenges. Ernest has already told the Bishop that he will take him on a "Journey through hell". He tells Avis: "But I tremble for you when I think of all you are to prove by Jackson's arm" (349); the scene has been set for exposure. Avis's investigation begins with visiting Jackson in person; he tells her the cause of the accident: "I worked seventeen years in them mills, an' I've took notice that most of the accidents happens just before whistle-blow. I am willing to bet that more accidents happen in the hour before whistle-blow than in all the rest of the day. A man ain't so quick after workin' steady for hours. I've seen too many of 'em cut up an' gouged an' chawed not to know" (350-351).

Avis' investigation turns up various things. She talks with Jackson's lawyer, a weak, inefficient lawyer who whines most of the time. London has the opportunity to make comments on the law and lawyers. Avis asks the lawyer "How his [Jackson's] answers could be damaging if he had the right on his side?" This is a damaging comment on the law. In reply the lawyer states: "What's right got to do with it? All my studying of them [books], has taught me that law is one thing and right is another thing" (352). The footnote informs the reader that "the function of the corporation lawyer was to serve, by corrupt methods, the money-grabbing propensities of the corporations" (353).

An important device used for satire is the use of animal and their characteristics for exposing the evils and follies. London uses the image of the wolf to depict the masters of his contemporary society. They are depicted wicked and strong, like wolves who do not spare weak creatures, like Jacksons. One of the footnotes runs: "Men preyed upon one another like ravening wolves. The big wolves ate the little wolves, and in the social pack Jackson was one of the least of the little wolves" (353).

In an encounter with the foreman of the Company, Avis is shocked to see that the latter suddenly "ripped out a savage oath". The footnote related to this event states: "It is interesting to note the virilities of language that were common speech in that day, as indicative of the life, 'red of claw and fang'; that was then lived" (356).

In her quest for truth and justice, Avis realizes that this "boastful" civilization is "soaked in blood"; the hypocritical society has been feeding her out of the toil and misery of workingmen, like Jackson.

Northrop Frye in Anatomy of Criticism (1970), describes a form of satire where the target is too powerful and must be confronted by an equally strong giant-killer, who "has to bear down his opponent by sheer weight of words, and hence be a master of that technique of torrential abuse which we call invective" (Frye 236). Here, Ernest Everhard is both, the cool and intelligent giant-killer who prods giants like Bishops, lawyers, and the oligarchs to incoherent fury, and also a master of torrential abuse.

Ernest unmasks the smug righteousness of the masters who assume that they are quite sure that they are right in what they are doing. That is the crowning absurdity of the whole situation. They are so "tied by their human nature that they can't do a thing unless they think it is right. They must have sanction for their acts" (365). This is a sharp and direct condemnation of the oligarchs, for their righteousness. The idle rich do not know humankind or society; they only know business.

While Ernest Everhard speaks, Wickson sneeringly remarks the term "Utopian". This gives Jack London another opportunity to comment through Meredith. The footnote points out:

The people of that age were phrase slaves. The abjectness of their servitude is incomprehensible to us. So befuddled and chaotic were their minds that the utterance of a single word could negative the generalizations of a lifetime of serious research and thought. Such a word was the adjective Utopian. The mere utterance of it could damn any scheme, no matter how sanely conceived, of economic amelioration or regeneration. (373)

This is an acute criticism of the narrow-minded masters of London's times.

The confrontation between Ernest Everhard and Wickson is cool, cynical and bitter. Each vows that his class shall seize power and grind the other down. The cultured, educated rich people can snarl and fight exactly like the working class men. Humanity is stripped of all its veneer of culture and civilized conduct, and exposed in its raw, savage greed for power. Wickson, shamelessly, boasts that their answer will be in terms of lead, not words, and asserts: 
When you reach out your vaunted strong hands for our palaces, in roar of shell and shrapnel and in whine of machine-guns will our answer be couched. We will grind you revolutionists down under our heel, and we shall walk upon your faces. The world is ours; we are its lords, and ours it shall remain. As for the host of labor, it has been in the dirt since history began, and in dirt, it shall remain so long as I and mine, and those that come after us have the power. There is the word. It is the king of the words - Power. Not God, not Mammon, but Power. Pour it over your tongue until it tingles with it. Power. (384)

Unashamed and proud boasting of one's own brutality is another device of satire, which arouses disgust in the reader. Ernest Everhard expects nothing better from the brutal capitalist class in its methods of suppressing the working class. He tells them: "We know, and well we know by bitter experience, that no appeal for the right, for justice, for humanity, can ever touch you. Your hearts are as hard as your Heels with which you tread upon the faces of the poor" (384). The statement of Wickson is a prologue to the horrible and disastrous fate of the working class at the hands of the Oligarchy. The pessimistic action of the novel stems from the statement uttered by this influential member of the rising Oligarchy. London wanted to convey exactly these facts to his comrades in the Socialist Party.

The rise and progress of the Oligarchy leads to the somber events that take place in the novel. There is progressive suppression of the proletariat and the workers. Avis' own surroundings are the first to be affected by the rise of the Oligarchy. Her father is discharged from the university and his book Economics and Education, which was becoming a menace to the capitalist system, is suppressed. Not satisfied with this, the oligarchs have the dividends earned by Avis' father from the Sierra Mills, stopped; he is also forced to vacate his house. He is compelled to get a house in the slums of San Francisco where Avis and Ernest get married. The destruction of organized labor begins; for this purpose, the Oligarchy uses "The Black Hundred", the army of strike breakers. Simultaneously, the middle class, too, is punished and exterminated.

The events affect Ernest, who is gradually disillusioned. He loses hope in the peaceful political process which has been the motto adopted by socialists in their move to replace the capitalist system. He realizes the ineffectiveness of the peaceful political process, and believes: "We [the socialists] are beaten. The Iron Heel is here. I had hoped for a peaceable victory at the ballot box. I was wrong. Wickson was right. We shall be robbed of our few remaining liberties; the Iron Heel will walk upon our faces; nothing remains but a bloody revolution of the working class" (435). The warning given by Ernest, is ignored by his fellow-socialists, who continue to hold the view that their ultimate goal, the socialist utopia, could be achieved only through election. He criticizes his comrades' consistent blindness to reality. They plan to send him to Congress, and think that everything will be all right, but he does not believe it. "And when they [the oligarchs] take me out of Congress," Ernest replied coldly, "and put me against a wall, and blow my brains out- what then? Then we'll rise in our might," a dozen voices answered at once. "Then you'll welter in your gore," was his retort, "I've heard that song sung by the middle class, and where is it now in its might?" (436). Through this sarcastic dialogue, London reproaches his fellow-socialists who underestimated the destructive power of the masters.

Bishop Morehouse has turned Christ-like and "is rushing on to his Gethsemane"; he is, in the eyes of Avis Everhard, "Sod's hero", and a martyr of the revolution. The tragic fate of the Bishop can also be similar to the fate of Ernest Everhard himself who "toiled as few men ever toiled, and all his lifetime he toiled for others, all his life sang the song of man. And he did it out of sheer love of man, and for man he gave his life and was crucified" (440).

The disastrous end of the revolution begins when the socialists win seats in the Congress. The Iron Heel destroys the labor castes and the middle class parties, like the Grangers who have won a few seats in the Congress. The Oligarchy wants violence and uses its "agents - provocateurs" to provoke laborers to create disorder; this disorder is a pretext for the troops to massacre the laborers. The only way to fight against the Oligarchy is through secret warfare by organizing "Fighting Groups". This somber picture is presented with bitter irony. The murder of democracy by the Oligarchy takes place sooner than expected; in a conspiracy planned by the Oligarchy in the Senate in 1913, the Socialist Congressmen are rounded-up, arrested and tried on false charges of exploding a bomb in the Congress. It is prior to this foul drama by the Oligarchy that Ernest bitterly attacks the Congressmen - Republicans and Democrats alike. In a bitter invective, he exposes their hypocrisy. Ernest calls them: "spineless, panderers and the creatures of the Plutocracy", who talk "verbosely in antiquated terminology of your love of liberty, and all the while you wear the scarlet livery of the Iron Heel" (487). Bitterly, he tells them: "Surely there must be a hell, for in no less place could it be possible for you to receive punishment adequate to your crimes. So long as you exist, there is a vital need for a hell-fire in the Cosmos" (488). 
The under-ground warfare against the Oligarchy is taken up by the Fighting Groups. Both the Oligarchy and the Revolutionaries are infiltrated by spies from the enemy camps; the revolutionary leaders are forced to disguise their real identities in order to accomplish the task of leading the revolution. Ernest is arrested and kept in custody but manages to escape along with some other leaders, and begins to lead the revolution from a hiding-place.

Avis Everhard is forced to assume the disguise of the daughter of an oligarch in order to travel freely in the country. She is disguised as Felice Van Verdighan, who is accompanied by three house cleaners and a lapdog. The footnote comments on this ridiculous wasteful way of life in London's times. For the 27th century reader, Meredith explains: "This ridiculous picture well illustrates the heartless conduct of the masters. While people starved, house cleaners waited upon lap dogs. This was a serious masquerade on the part of Avis Everhard. Life and death and the Cause were in the issue; therefore the picture must be accepted as a true picture. It affords a striking commentary of the times"(495). London exposes the callousness of the Oligarchs who suppressed the farmers and grabbed their land in order to build magnificent estates for themselves. The disguised Avis chooses the very estate of the arch-oligarch, Wickson, as a hiding place. She is not surprised at the callousness of the masters who do not even hesitate to demolish a "state home for the feeble-minded" in order to "make room for the deer" (497).

In 1918, all of a sudden, hell breaks loose; the Iron Heel, expectant of the forthcoming events, sets out to give a horrifying lesson to the proletariat. Through its spies, the Iron Heel fans the already roaring flames and finds it the right time to crush the revolutionaries,

As Avis Everhard observes, Chicago resembles a modern jungle, where the masses have not yet changed from primitive man. It is the same Jungle of Upton Sinclair's satiric novel, The Jungle. The people of the abyss are up, at last, roaring at the masters, "snarling and growing carnivorous", drunk with terrible hatred and lust for the blood of those who have been perpetually tormenting them; these miserable beasts are all let loose. London describes the mob of the people of the abyss, who are all fiend-like, mad with drink and wrong. London uses the method of exaggeration to describe the mob: "Great hairy beasts of burden, wan faces from which vampire society had sucked the juice of life, bloated forms swollen with physical grossness and corruption, festering youth and festering age, faces of fiends, crooked, twisted, misshapen monsters blasted with the ravages of disease and all the horrors of chronic innutrition"(535). It is a disgusted and disgusting portrayal of a mindless mob. This grotesque mass of humanity is the helpless victim of the more powerful and intelligent group of human beings. Jack London, like Swift, is angry at humanity - both the victim and the victimizer.

The novel is a projection into the near future-1912-32; it is a logical development of the prevailing conditions in 1907-8 when the book was written. In her essay, Susan Ward, points out these similarities between the time of the novel 1912-32, and that of the society of 1908 - by stating:

The projected tactics of the ruling class [of London's times] as its members try to suppress the revolutionaries afforded London opportunity for implied socialist criticism within the body of the manuscript. Although practices, recorded by Avis, are carried out by a 'future' government, that government is clearly an extension of the power structures dominating the American economic scene in 1908. By implication, the novel suggests that the ruling class in America had the power to assume the role of the Oligarchy in the novel. By this means, the entire governmental structure of early twentieth- century America is called into question. The suggestion that he [London] had seen them [the oppressive tactics] practiced by the ruling class of his own day is not entirely absent from the novel. ("Ideology for the Masses: Jack London's The Iron Heel," 171-172)

The Soviet critic, Bykov, maintains that The Iron Heel is a blow to utopias, which aim at a better society by peaceful means. Bykov observes: "The Russian Revolution of 1906 had not only provided London with certain details for his novel, but had also convinced him of the precariousness of the hope to achieve power for the working-classes by peaceful means" (Brown, 1962, 107). Bykov considers London as a man who defended the interests of the proletariat and should be remembered in the history of American literature.

\section{CONCLUSION}

The picture of utopia as it develops and emerges is somberly and bitterly satirical and it helps London in voicing his protest. There is no laughter but only shocked disgust and loathing that the reader can feel at the unabashed cruelty of the Oligarchy. London's tone here is akin to the tone of his predecessor Jonathan Swift. With cool reasonableness and logic, London paints a picture of the complete success of the establishment of the Oligarchy and its cynical moral code. 
That the Oligarchy should be so successful, is a painfully mocking comment on humanity. On the one hand is the section that gets to power and secures itself by cruel and cynical suppression; on the other is the mass of humanity, too weak, too stupid, too lethargic and frightened to escape from the situation.

London's The Iron Heel is a part of an important tradition of negative utopias; it satirizes the high ideals and principles of the pacifists. These ideals, are depicted by London as vain and purposeless; they are helpful only to the Oligarchy which takes advantage of the proletariat and causes it to be reduced to working animals

\section{REFERENCE LIST}

Frye, N. (1970). Anatomy of Criticism: Four Essays. New York: Methuen \& Co. Ltd.

Pizer, D. (1982). Jack London: Novels and Social Writings. New York: Literary Classics of the United States.

Simpson, P. (2003). On The Discourse of Satire: Towards a Stylistic Model of Satirical Humour. Amsterdom: John Benjamins Publishing Company.

Hodgart, M. (1969). Satire. London: Weidenfeld and Nicolson.

Pollard, A. (1970). Satire. Critical Idiom Series, Vol. 7. London.

Ward, S. (1983). "Ideology for the Masses: Jack London's The Iron heel." In Critical Essays on Jack London, Edited by Jacqueline Tavernier-Courbin. Boston: G. K. Hall. 